Article

\title{
Participatory Irrigation Management and Irrigation Water Use Efficiency in Maize Production: Evidence from Zhangye City, Northwestern China
}

\author{
Qing Zhou ${ }^{1,2,3}$, Xiangzheng Deng ${ }^{1,2, *}$, Feng Wu ${ }^{1,2}$, Zhihui Li ${ }^{1,2}$ and Wei Song 4 \\ 1 Institute of Geographic Sciences and Natural Resources Research, Chinese Academy of Sciences, \\ Beijing 100101, China; zhouq.14b@igsnrr.ac.cn (Q.Z.); wufeng@igsnrr.ac.cn (F.W.); \\ lizh.12b@igsnrr.ac.cn (Z.L.) \\ 2 Center for Chinese Agricultural Policy, Chinese Academy of Sciences, Beijing 100101, China \\ 3 University of Chinese Academy of Sciences, Beijing 100049, China \\ 4 Key Laboratory of Land Surface Pattern and Simulation, Institute of Geographic Sciences and Natural \\ Resources Research, Chinese Academy of Sciences, Beijing 100101, China; songw@igsnrr.ac.cn \\ * Correspondence: dengxz@igsnrr.ac.cn; Tel.: +86-106-488-8980
}

Received: 28 September 2017; Accepted: 23 October 2017; Published: 30 October 2017

\begin{abstract}
Water has become increasingly scarce in northwestern China due to climate change, economic growth and burgeoning population. Improving agriculture water use efficiency is of strategic significance in promoting socio-economic water productivity for arid and semi-arid inland river basins. Based on the household-level data collected in Zhangye City, which is located in the middle reaches of Heihe River Basin (HRB) in northwestern China, irrigation water use efficiency (IWUE) of maize is estimated based on stochastic frontier analysis. The impacts of influential factors, especially the participatory irrigation management (PIM) through water user associations (WUAs), on IWUE were further examined. Results show that the estimated average Technical efficiency (TE) and IWUE of maize production are 0.74 and 0.24 , respectively. The participation level in irrigation management is very low, with only $40 \%$ of the respondents participating in WUA meetings. In addition, most have a relatively superficial understanding of the roles and management scheme of WUAs. Empirical results show that though significantly positive, the magnitude of the impact of PIM on IWUE is relatively small. Households that participated in WUA meetings achieved only $0.002 \%$ higher IWUEs than those have never participated in. WUAs are not operating with their designed objectives. Consequently, reform of the traditional management form of WUAs to make them more transparent, fair, and extensively participated in among farmers is in urgently need. In addition, we also find that water price, source of irrigation water, irrigation technology adoption and famers' education level and farming experience also have significant positive impacts on IWUE.
\end{abstract}

Keywords: technical efficiency; irrigation water use efficiency; participatory irrigation management; stochastic frontier analysis; water user associations; Heihe River Basin

\section{Introduction}

Water scarcity has become a main challenge for the world with increasing demand resulting from burgeoning population, accelerating economic development, and rapid urbanization [1,2]. Globally, agriculture activities consume the vast majority of freshwater among irrigation withdrawals, representing approximately $70 \%$ of total water use, and the ratio is even higher in many developing countries [3]. The dilemma between water scarcity and socio-economic development is more pronounced where climate change threatens to exacerbate the situation with a predicted reduction in water availability and an increase in agricultural water demand in arid and semi-arid regions [4-6]. 
Although securing adequate water for agriculture in the future will be essential in order to maintain a high level of food self-sufficiencies, increasing water scarcity is particularly challenging to the agricultural sector. Competition for water between agriculture and nonagricultural activities will become fiercer in order to achieve higher water productivity $[7,8]$. It indicates that agriculture will not be given priority for any additional future allocations of water since water has higher marginal returns in industry and the residential sectors. Under such circumstances, improving irrigation water use efficiency (IWUE) is an imperative strategy to solve the water shortage problem and also a critical measure for achieving sustainable irrigated agriculture $[9,10]$.

IWUE is an important indicator for agriculture water use sustainability. IWUE means quite different things among agronomists and agriculture economists. For agronomists, IWUE is determined by rainfall, irrigation, soil moisture and crop evapotranspiration (ET) requirement. Such definitions mainly focus on engineering and agronomic techniques, and are measured through field experiments that do not consider water as an economic good [11,12]. In order to evaluate the economic performance of water in socio-economic system, water has been considered a primary input in combination with other inputs (land, labor, capital, etc.). The definition and measurement of IWUE is thus based on the concept of input-specific technical efficiency, which represents an optimal allowance of the inputs at the production frontier [13]. As compared to previous physical measures used in the literature, this measure takes into account the economic attributes rather than an engineering meaning.

There have been several empirical studies that analyzed the IWUE of agricultural production from an economic perspective [14-17]. These studies intended to measure the economic efficiency of water, study its determinants, and to compute efficiency as a tool for benchmarking or only estimating efficiency. Their results show that IWUE varies greatly in different regions and the factors that influence IWUE are complicated, including farm household characteristics (e.g., age, education, family labor, income levels and access to credit), land characteristics (e.g., farm size, degree of land fragmentation, soil quality and land ownership) and households' access to other resources such as extension services and farm skills training [10,18]. Besides, technology was considered an essential tool for increasing agricultural IWUE. Researchers found that the deficit irrigation could significantly increase IWUE [19]. From above analysis, we can see that early research mainly pays attention to the impacts of water conservancy projects, farmers' choices and decisions in production, and technological progress on agricultural IWUE. With more restricted water regulations such as the red line of IWUE implemented, people pay more attention to the influence of institutional factors such as water price, property rights systems, and irrigation management systems on IWUE. The traditional government-oriented management form of irrigation is challenged and the lack of farmers' self-management is considered a key factor to the low IWUE.

Since the 1990s, the paradigm of water resource management has shifted from government-oriented towards participatory management and adaptive governance [20-23]. Decentralized reforms of irrigation management have been carried out to transfer the responsibility for the management of irrigation systems from the government to farmers' voluntary associations. This emphasis on "water users involved" in the core concept of irrigation management reform is called participatory irrigation management (PIM). To promote participatory irrigation management and the full involvement of small-scale farmers, farmers' water users associations (WUAs) have become increasingly common in the arid region of northwestern China [24-26]. WUAs played a critical role in promoting the agriculture water reform at the community level. As the organizational foundations for water allocation, they help create efficient and equitable policy environment for farmers' water use [27-29].

Despite the widespread application as remedies for poor irrigation system performance, the actual effectiveness of PIM is still under debate and contested. Research in support of PIM argues that participatory management through WUAs contributes to improving irrigation management by providing farmers with opportunities to learn up-to-date water-saving technologies. Farmers share important experience and ideas that could lead to practical, achievable and acceptable solutions 
to water-related problems [23,30-32]. Others show that WUAs help to improve channel quality and ensure the positive significance of water charges $[29,30]$. In addition, WUAs may play an important role in lowering the transaction cost in water trading between agriculture and other sectors, and thus promoting the development of water markets [33]. However, other empirical studies on the performance of the PIM find that most WUAs have not been universally successful in either saving water or improving farm incomes $[34,35]$. The main reason for the ill performance is due to their lack of cooperation with other institutions and the absence of training for WUA managers [36,37].

Considering that few studies have investigated the impacts of PIM through WUAs on IWUE and even fewer use a general descriptive discussion and lack in-depth standardized quantitative research, the main objective of this study is to analyze IWUE from a production frontier perspective and investigate the impacts of PIM on IWUE. It is of theoretical and practical significance to establish the management model that is suitable for the actual situation in different regions and adopt effective participatory mechanisms to promote the sustainable use of water resources. Therefore, this study lends empirical evidence to the debate regarding the impact of participatory irrigation water management policies on agricultural production and will further lend support to irrigation water management strategies made.

The paper is organized as follows. Section 2 introduces the methodology for measuring IWUE and specifies the empirical model. Section 3 describes the empirical data used to analyze the proposed models in the context of irrigation water use of the agricultural production system in the middle reaches of Heihe River Basin, China. Results and main findings are presented in Section 4. Finally, the paper concludes by highlighting the policy importance.

\section{Methodology}

IWUE is commonly defined as yield per cubic water [18]. However, this measure is biased and inappropriate, for it ignores the fact that yield is produced by multiple inputs, including not just water but also land, fertilizers, seeds, machinery and labor. So IWUE in this paper is defined as the ratio of the minimum amount of water needed to produce a given level of output, conditional on levels of other inputs, to the amount of water actually applied [14]. Usually, the technical efficiency of irrigation water use was estimated first. Traditionally, there are broadly two approaches to obtain efficiency estimates in the literature: parametric techniques (i.e., stochastic frontier analysis (SFA)) and non-parametric techniques (i.e., data envelopment analysis (DEA)). The advantage of the parametric technique is that it provides the researcher with a robust framework for performing hypothesis testing, and the construction of confidence intervals.

Following Battese et al., the general stochastic production function for panel data is [38]:

$$
y_{i t}=f\left(x_{i t}, w_{i t} ; \beta\right) \exp \left(v_{i t}-u_{i t}\right)
$$

For farmer $i$, production function (1) describes output $y_{i t}$ at period $t$, as a function of a vector of inputs $x_{i t}, w_{i t}$ is the amount of irrigation water used, $\beta \mathrm{s}$ are the coefficients of input variables, and an error term is made up of two components: $v_{i t}$ is the systematic error term, and $u_{i t}$ represents the technical inefficiency during the production which reflects the shortfall of a farmer's output from the production frontier. In addition, it is non-negative.

Cobb-Douglas and Translog functions are the two most commonly used functional forms for production function. The likelihood ratio test is used to determine which function form fits our data (described in the next section) better. With a $p$-value of 0.01 , we reject the null hypothesis of a Cobb-Douglas functional form. A Translog production function was employed in the analysis. For the 
$i$-th farmer in period $t$, the Translog stochastic frontier production function with different inputs is as follows:

$$
\begin{aligned}
\ln y_{i t} & =\beta_{0}+\beta_{1} \ln \text { labor }_{i t}+\beta_{2} \ln \text { capital }_{i t}+\beta_{3} \ln \text { land }_{i t}+\beta_{4} \ln \text { water }_{i t}+\beta_{5} \ln \text { labor }_{i t} \ln \text { water }_{i t} \\
& +\beta_{6} \ln \text { capital }_{i t} \ln \text { water }_{i t}+\beta_{7} \ln \text { land }_{i t} \ln \text { water }_{i t}+\beta_{8} \ln \text { labor }_{i t} \ln \text { capital }_{i t} \\
& +\beta_{9} \ln \text { labor }_{i t} \ln \text { land }_{i t}+\beta_{10} \ln \text { land }_{i t} \ln \text { capital }_{i t}+\beta_{11}\left(\ln \text { water }_{i t}\right)^{2} \\
& +\beta_{12}\left(\ln \text { labor }_{i t}\right)^{2}+\beta_{13}\left(\ln \text { capital }_{i t}\right)^{2}+\beta_{14}\left(\ln \text { land }_{i t}\right)^{2}+v_{i t}-u_{i t}
\end{aligned}
$$

where $y_{i t}$ is the output of maize. The four inputs considered in the application are land, labor, capital (a combination of inputs of seed, fertilizer, pesticide, and machine), and water. Following Reinhard et al., IWUE for farmer $i$ can be obtained by setting actual production equal to production under technical efficient condition $\left(u_{i t}=0\right)$, namely, using minimum feasible irrigation water while producing the same level of output $\left(y_{i t}\right)[14]$.

$$
\begin{aligned}
\ln y_{i t} & =\beta_{0}+\beta_{1} \ln \text { labor }_{i t}+\beta_{2} \ln \text { capital }_{i t}+\beta_{3} \ln \text { land }_{i t}+\beta_{4} \ln \text { water }_{i t}^{e}+\beta_{5} \ln \text { labor }_{i t} \ln \text { water }_{i t}^{e} \\
& +\beta_{6} \ln \text { capital }_{i t} \ln \text { water }_{\text {it }}^{e}+\beta_{7} \ln \text { land }_{i t} \ln \text { water }_{\text {it }}^{e}+\beta_{8} \ln \text { labor }_{i t} \ln \text { capital }_{i t} \\
& +\beta_{9} \ln \text { labor }_{i t} \ln \text { land }_{i t}+\beta_{10} \ln \text { land }_{i t} \ln \text { capital }_{i t}+\beta_{11}\left(\ln \text { water }_{i t}^{e}\right)^{2} \\
& +\beta_{12}\left(\ln \text { labor }_{i t}\right)^{2}+\beta_{13}\left(\ln \text { capital }_{i t}\right)^{2}+\beta_{14}\left(\ln \text { land }_{i t}\right)^{2}+v_{i t}
\end{aligned}
$$

when (3) - (2), we have:

$$
\left.\beta_{4}+\beta_{5} \ln l a b o r_{i t} \ln I W U E_{i t}+\beta_{6} \ln c_{a p i t a l} l_{i t} \ln I W U E_{i t}+\beta_{7} \ln l a n d_{i t} \ln I W U E_{i t}+\beta_{11}\left(\ln I W U E_{i t}\right)^{2}+2 \beta_{11}\left(\ln w_{\text {ater }}\right)_{i t}\right)^{2}+u_{i t}=0
$$

where IWUE $E_{i t}=\frac{\text { water }_{\text {it }}^{e}}{\text { water }_{i t}}$.

Therefore, IWUE can be obtained:

$$
I W U E_{i t}=\exp \left\{\left[-\xi_{i} \pm\left(\sqrt{\xi_{i}-2 \beta_{11} u_{i t}}\right)\right] / 2 \beta_{11}\right\}
$$

where $\xi_{i t}=\frac{\partial \ln y_{i t}}{\partial \ln \text { water }_{i t}}=\beta_{4}+\beta_{5} \ln$ labor $_{i t}+\beta_{6} \ln$ capital $_{i t}+\beta_{7} \ln$ land $_{i t}+2 \beta_{11} \ln$ water $_{i t}$.

Since IWUE values were calculated from the estimates of the parameters in (4) and (5), driving factors for IWUE cannot be obtained from the one-step approach, so a two-step approach is needed to assess the influencing factors of IWUE. Traditional OLS estimation is biased and inconsistent due to the dependent variable $I W U E_{i t} \in$ to $(0,1)$. Tobit model based on the maximum likelihood estimation method will be unbiased and effective. It can be expressed as a piecewise function. $Z_{i t}$ is a vector and includes a set of factors that influence the IWUE which will be described later. The Tobit model can be expressed as follows:

$$
I W U E_{i t}= \begin{cases}0 & \text { if } \partial_{0}+\sum \partial_{i} Z_{i t}^{\prime}+\varepsilon_{i t} \leq 0 \\ \partial_{0}+\sum \partial_{i} Z_{i t}^{\prime}+\varepsilon_{i t} & \text { if } 0<\partial_{0}+\sum \partial_{i} Z_{i t}^{\prime}+\varepsilon_{i t}<1 \\ 1 & \text { if } \partial_{0}+\sum \partial_{i} Z_{i t}^{\prime}+\varepsilon_{i t} \geq 1\end{cases}
$$

IWUE can be influenced by various factors. Following previous literature $[10,16,17,27,39]$, we group the critical factors into four categories, which were shown as follows:

$$
I W U E_{i t}=\partial_{0}+\partial_{1} H_{i t}+\partial_{2} L_{i t}+\partial_{3} W_{i t}+\partial_{4} P_{i t}
$$

The vector $H_{i t}$ includes a set of factors that measure farmers' household characteristics. Household income and number of laborers may influence IWUE because they are the sources of capital and labor inputs in agricultural production. Age and farming years are also important variables representing farmers' farming experience, which may help increase IWUE. At the same time, education may also play a role, for the ones with higher education may be more likely to adopt new agriculture technologies and reduce water use. 
$L_{i t}$ is the vector of farmers' land use variables. Total land holding represents farmers' production scale, which may have impacts on IWUE. The number of plots a household owns measures the degree of land fragmentation. Yin et al. showed that if the land is too scattered, it is hard to reach economies of scale, and the more fragmented the land is, the more difficult it is for a household to irrigate all the plots [10]. Farmers' planting structure, a dummy variable that if a farmer only plants maize equals one, otherwise equals zero, may also influence IWUE.

The vector $W_{i t}$ includes water-related technology and management variables. Infrastructure and technology inputs in irrigation will have impacts on IWUE. Cement canal lining and plastic film are the main water saving technologies adopted in the study area. Two dummy variables were used to show whether farmers have adopted these two technologies respectively. The source of irrigation water may also influence IWUE. Farmers achieve higher IWUEs when groundwater was used compared to those who only use surface water shown in previous studies [36,40]. Groundwater is an important source of irrigation in the study area, so we include a variable to represent the source of irrigation water. If groundwater was used, the value of the variable is 1 , if farmer only uses surface water in irrigation the value will be zero. Water price is an important management instrument that can provide incentives to adopt new technologies, and thus saving water and improving IWUE. In addition, the effect of irrigation water price policy is very different in different natural environments and agricultural production conditions; empirical studies are needed to specify the effectiveness of water price on IWUE improvement. In this study, we have gathered farmers' water fee in irrigation in the survey. Farmers' payment for irrigation water may reflect the price level of irrigation water, and in our survey, most farmers pay for irrigation water by area. So we include irrigation water fee to investigate whether water price has significant influence on farmers' IWUE in our study area.

The variables of interest are farmers' participation in WUA, which was represented by $P_{i t}$. Traditional irrigation water resource management systems are increasingly replaced by participatory management schemes through water users associations (WUAs) in China. In addition, the empirical study from Zhang et al. shows that WUAs play a significant role in promoting water productivity among the households in northern China [30]. However, whether PIM in WUA will have significant impacts on IWUE is rarely discussed in previous studies. So in this study, we try to figure out whether farmers' participation in WUA helps to improve IWUE by including two dummy variables representing farmers' participation level in WUA management. Firstly, there is a dummy variable whose value equals one if the farmer has attended in the WUA meetings, otherwise equals zero. This will distinguish between the IWUE of farmers who have attended in water management and farmers who have not. However, the attendance information is not sufficient to address farmers' participation management status in irrigation management. Therefore, we include a dummy variable to identify farmers who have been actively involved in the management by expressing their opinions at the meetings. The value of the dummy equals one if farmer has expressed his or her opinion in the meetings, and otherwise zero.

\section{Data Collection and Description}

The analysis was based on the dataset collected by the author and collaborators in August 2015, in Zhangye City in the middle reaches of Heihe River Basin in northwestern China. The field area was a typically arid and semi-arid agriculture zone with an average annual precipitation less than $200 \mathrm{~mm}$. Zhangye City is an important agricultural production base that occupies $95 \%$ of cultivated land $\left(2668 \mathrm{~km}^{2}\right)$, includes $91 \%$ of the population, and generates more than $80 \%$ of GDP of the Heihe River Basin. It is also one of the 12 key national commercial grain bases due to its abundant supply of wheat, corn, rice, oilseed rape, flax and other crops. Wheat and maize production accounts for almost $90 \%$ of households' land use. In our study area, agriculture water demands are mainly met from irrigation since the annual precipitation is less than $200 \mathrm{~mm}$. Irrigation agriculture is the largest user of water, accounting for nearly $90 \%$ of the total water use. 
The surveys were conducted in 6 counties in the middle reaches of Heihe River Basin. A stratified random sampling strategy was used to select farm households in our study area. Firstly, two townships were selected in each county with varying degrees of water scarcity. Next, two villages in each town were chosen randomly. Within each village, 10 households were randomly selected. In total, 24 villages and 170 farm households were surveyed. The distribution of the farm households is shown in Figure 1. In each household, the decision-maker for agricultural production activities, who was able to answer detailed questions about their inputs and outputs in agricultural production and the local water resource management, was selected as the respondent. Face-to-face interviews were conducted by a group of interviewers consisting of Master and Ph.D. students from the Center of Chinese Agriculture Policy in University of Chinese Academy majoring in Agriculture Economics. Before the interviews, a preliminary survey was held to test the structure of the questionnaire and uncover possible misinterpretations of the questions and ambiguous responses. Based on the outcome of this survey, ambiguous and unclear questions were revised.

Our survey contains agricultural production information in the years 2010 and 2014. The questionnaire includes questions about farmers' characteristics household information, input and output information of agricultural production, water management information and related water policies. Questions relating to the participation in irrigation management, including how many meetings are held during one-year during irrigation times, how many farmers are involved in each meeting, how many times is there irrigation technology training per year, whether the chairman engages in agriculture production or not, and so on. Although virtually all farmers produce several crops, we only consider maize farmers, which is the main crop irrigated. Finally, three groups of households were dropped in our analysis. The first group includes households that did not plant maize in either study period. In addition, in order to obtain a balanced panel dataset, we also dropped samples that only planted maize in one year. The second group includes households that did not irrigate maize at all. The third group is households that lack information of the volume of water used. With exclusion of these samples, the final survey data contains 78 households and 156 samples totally.

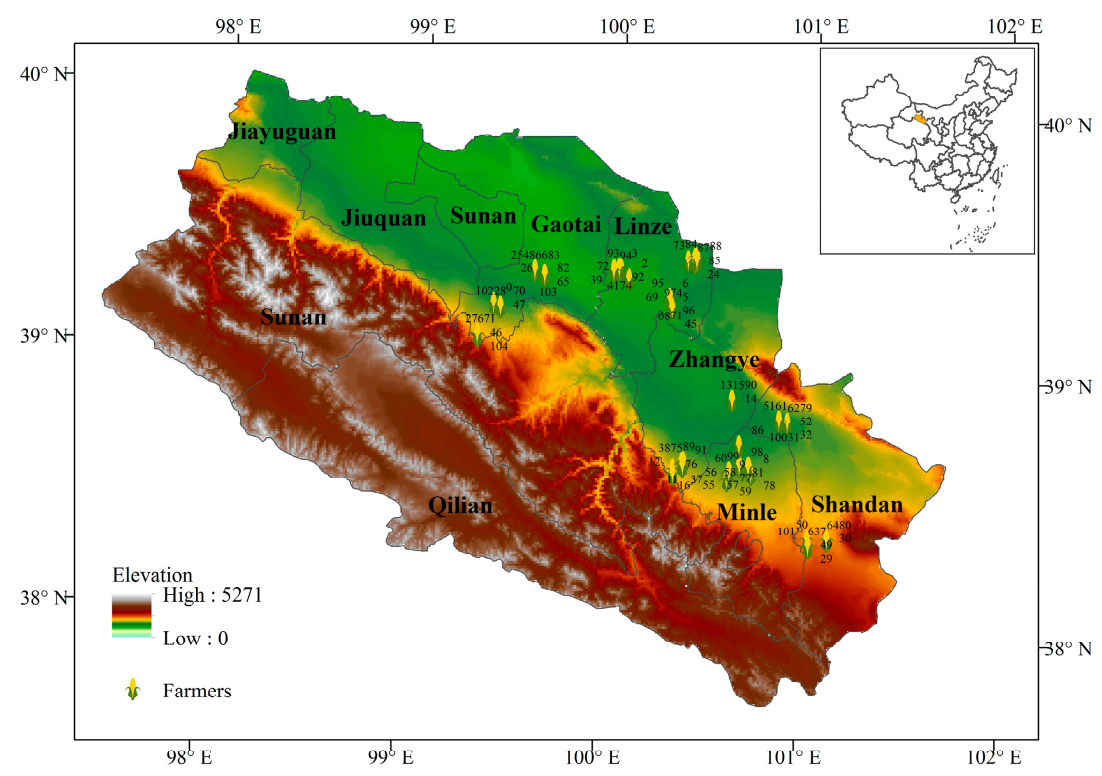

Figure 1. The administrative counties in the middle reaches of Heihe River Basin and the geographical distribution of our samples.

The summary statistics of the farm household characters and input and output information in maize production are shown in Table 1. In our sample area, the average total household land holding is $19.58 \mathrm{mu}$ (1.31 hectare) and the average land input in maize production is $4.1 \mathrm{mu}$. Maize is the main crop in Zhangye City and we only consider maize production in our study. Agricultural 
income only accounts for $46 \%$ of the total household income on average. We also find that about $84 \%$ of households have at least one member participating in off-farm employment. The average age of the farm respondents is 48 , which reflects the aging problem in China's agricultural sector. The average education years of farmers are 9, meaning that most farmers receive a junior high school education, which also indicates that farmers' educational attainment has been improved. The yield of maize per mu varies from $384 \mathrm{~km}$ to $1150 \mathrm{~km}$ in our study area. The surface water and groundwater used are 778 and 500 cubic meters per mu on average in the whole growth period. During our survey, we found that about $60 \%$ of farmers only use surface water and $20 \%$ use only groundwater for irrigation. Charges for water vary significantly in the study area. The forms of charges are also different in different irrigation districts including charging by area (Yuan per mu), by irrigation time (Yuan per hour), and by water used (Yuan per cubic meter). Here we unified them into Yuan per mu for it is the more widely adopted charge form in the study area. Other input information including fertilizer, seed, manure and labor are listed in the table.

Table 1. Descriptive statistics.

\begin{tabular}{|c|c|c|c|c|}
\hline Variables & Max & Min & Mean & S.D. \\
\hline Total income (Yuan) & $1,124,000$ & 12,925 & 79,917 & 114,687 \\
\hline Farm income (Yuan) & 120,000 & 5000 & 36,828 & 23,272 \\
\hline Cultivated land area (mu) & 100 & 2 & 19.6 & 13.7 \\
\hline Age (years) & 74 & 28 & 48.02 & 11.17 \\
\hline Education (years) & 16 & 0 & 9.26 & 3.09 \\
\hline Farming experience (years) & 50 & 0 & 25.56 & 11.73 \\
\hline Yield of maize $(\mathrm{kg} / \mathrm{mu})$ & 1150 & 300 & 732 & 384.87 \\
\hline Area of maize $(\mathrm{mu})$ & 30 & 4 & 4.1 & 5.6 \\
\hline Mask (Yuan/mu) & 104 & 0 & 40.38 & 13.86 \\
\hline Seed (Yuan/mu) & 180 & 21 & 72.63 & 26.83 \\
\hline Water fee (Yuan/mu) & 234 & 8 & 92.13 & 37.09 \\
\hline Fertilizer (Yuan/mu) & 500 & 68.5 & 253.62 & 79.61 \\
\hline Pesticide (Yuan/mu) & 194.24 & 0 & 41.7 & 37.16 \\
\hline Hire labor (Yuan/mu) & 1000 & 0 & 114.75 & 142.83 \\
\hline Service fee (Yuan/mu) & 240 & 0 & 7.811 & 31.01 \\
\hline Other inputs (Yuan/mu) & 100 & 0 & 1.15 & 9.574 \\
\hline Labor (days) & 10.92 & 0 & 5.53 & 2.09 \\
\hline Groundwater $\left(\mathrm{m}^{3} / \mathrm{mu}\right)$ & 1800 & 200 & 500 & 365.91 \\
\hline Surface water $\left(\mathrm{m}^{3} / \mathrm{mu}\right)$ & 1200 & 180 & 778 & 188 \\
\hline Observations & \multicolumn{4}{|c|}{156} \\
\hline
\end{tabular}

\section{Results and Discussion}

\subsection{Estimation of IWUE}

We first tested the Cobb-Douglas versus the Translog production function, the difference of the $\log$ likelihood test statistics follows a $\chi^{2}$ distribution [38]. The LR ratio is 83.57 , so we rejected the Cobb-Douglas specification at $1 \%$ significance level. The estimates of the Translog production function are reported in Table 2. This technical inefficiency ratio $\gamma$ indicates that technical inefficiency contributes $96.68 \%$ to the total variance of output. Equations (4) and (5) are estimated simultaneously in one step; the results were obtained using the method of MLE.

The output elasticity of maize yield with respect to each input is reported in Table 2. The coefficients for input factors represent the output elasticity of the input factors. Results indicate that capital significantly influences maize production, with an elasticity of 2.77 . This means that, ceteris paribus, a one percent increase in capital input leads to $2.77 \%$ increase of output value. The possible explanation of the positive relationship between capital and the yield of maize is that the increase in capital investment will lead to improvements of maize production conditions, such as more fertilizer input. Though not significant, the negative marginal remuneration of labor showing 
that increase in labor inputs will not improve a yield of maize. This is in accordance with the reality of China's rural labor surplus situation $[39,41]$. The coefficient of water is widely divergent in previous studies. Research from Wang et al. and Tang et al. showed that the coefficient of water is significantly positive, whereas Gadanakis et al. and Yin et al. found it was negative in their case studies $[10,17,27,41]$. The reason for the differences may be because of the different climatic conditions of the study area and various planting structure. The elasticity of water is -0.91 in our study, indicating that an increase in irrigation water will not lead to an increase in output. It can be concluded that there might be a slight overuse of water in maize production. The sum of elasticity with respect to the three inputs equals 1.24, indicating a (slightly) increasing return to scale [10].

Table 2. The estimated Translog production function.

\begin{tabular}{|c|c|c|}
\hline Variables & Coefficients & S.E. \\
\hline$\beta_{0}$ & 4.21 & 22.94 \\
\hline$\beta_{1}$ & $-0.62 *$ & 0.05 \\
\hline$\beta_{2}$ & $2.77^{* *}$ & 0.04 \\
\hline$\beta_{3}$ & 2.04 & 0.34 \\
\hline$\beta_{4}$ & $-0.91^{* * *}$ & 0.01 \\
\hline$\beta_{5}$ & 0.10 * & 0.08 \\
\hline$\beta_{6}$ & 0.19 & 0.30 \\
\hline$\beta_{7}$ & $-0.17^{*}$ & 0.09 \\
\hline$\beta_{8}$ & -0.33 * & 0.09 \\
\hline$\beta_{9}$ & 0.31 & 0.23 \\
\hline$\beta_{10}$ & $0.46^{*}$ & 0.07 \\
\hline$\beta_{11}$ & 0.02 & 0.28 \\
\hline$\beta_{12}$ & -0.05 & 0.15 \\
\hline$\beta_{13}$ & -0.27 & 0.45 \\
\hline$\beta_{14}$ & -0.01 & 0.12 \\
\hline$\sigma^{2}$ & $0.13^{* *}$ & 0.06 \\
\hline$\gamma$ & $0.97^{* * *}$ & 0.01 \\
\hline Log-likelihood Ratio & \multicolumn{2}{|c|}{183.57} \\
\hline Observations & \multicolumn{2}{|c|}{156} \\
\hline
\end{tabular}

Notes: Absolute value of t-statistics in parentheses. ${ }^{*}$ Significant at $10 \% ;{ }^{* *}$ Significant at $5 \%$; ${ }^{* * *}$ Significant at $1 \%$.

The frequency distribution of TE and IWUE estimates obtained by the SFA methods are shown in Figure 2. The average overall TE for the households is 0.74 , indicating that substantial inefficiencies occurred in farming operations of the sample farm households. The value of IWUEs demonstrated even larger inefficiencies. From the frequency distribution of IWUEs, we can find that the average IWUE for the whole sample is 0.24 . It is far lower than that of a farmer's agricultural production TE. When looking specifically at IWUEs, the results indicate that farmers fail to reach their overall technical efficiency levels. It implicated that there appears to be a considerable scope for the water use to be reduced, even with the technology currently available. It also means that if efficiency improves, it should be possible to reallocate a fraction of water to other water demands without really endangering agricultural production or the role small-scale irrigation might play for rural development. Some researchers have ascribed the substantial inefficiencies of irrigation to the poor performance of irrigation schemes and the absence of pricing mechanisms for water $[42,43]$. They suggested that the introduction of water charges will gradually trigger farmers' financial incentive to limit their water use or to invest in water-saving technologies. 


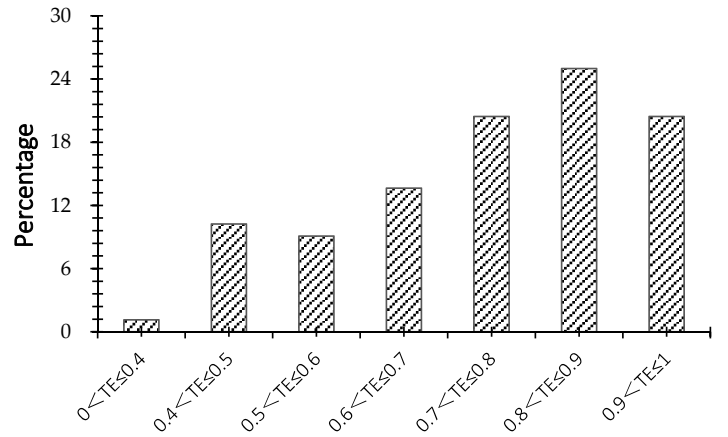

(a)

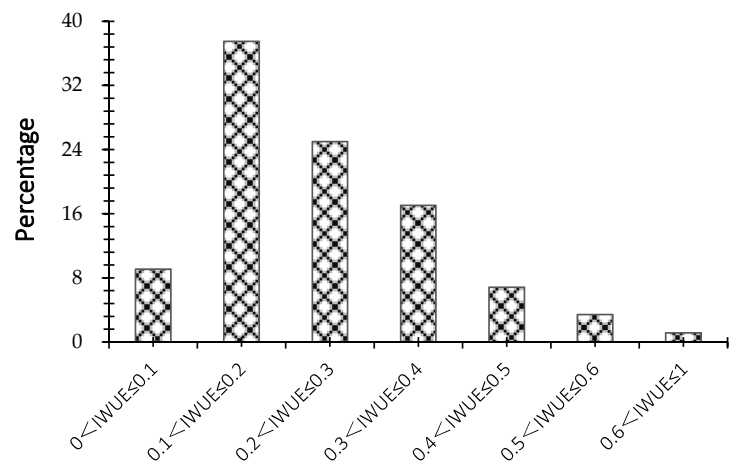

(b)

Figure 2. The frequency distribution of farm level efficiencies: (a) technical efficiency; and (b) irrigation water use efficiency of maize production in Zhangye City.

From recent IWUE studies in less developed countries, the values of IWUE vary from 0.20 to $0.74[39,44]$. The estimated IWUE in the study area is very low. There will be large scope for the IWUE to be improved in the study area. Though faced with serious water scarcity, agricultural water use is still rampant in arid northwestern China. Researchers have found that IWUE is generally lower in more water-scarce areas. They show that farmers' perception of water scarcity will influence their irrigation behavior. They tend to irrigate more when they were more vulnerable to drought [45]. Furthermore, the absence of market instruments is also the reason for the low IWUE. Water-scarce areas are usually in less developed areas in China. They receive more subsidies from central government on agricultural production. The economic view of efficient water use is not recognized and flood irrigation is pervasive because farmers have no incentive to save water.

\subsection{Farmers' Perceptions and Participation Level in WUAs}

WUAs were established in every administrative village of Zhangye City when IWRM was first implemented. They were organized by the local government to involve all small-scale farmers in water management, which helps ensure democratic decision-making, supervision in water-related affairs, and promotes cooperation in water management through self-organized community networks. Field surveys found that farmers' participation in irrigation management was mainly in the annual meetings of WUA (including the General Assembly and Executive Committee meetings) to consult and discuss on farmland irrigation-related affairs. The main hypothesis is that the more attending meetings, the higher the degree of participation in irrigation management, and the higher the likelihood of obtaining a relatively high IWUE.

Farmers' perceptions about WUAs were assessed by survey questions and statements, including farmers' understanding of WUAs, the degree of support for WUAs, and involvement in WUAs decision-making processes. Data from our surveys shows that $38 \%$ of the respondents did not clearly understand the purposes of the organizations (Table 3). About $75 \%$ of the respondents say that they can get the information when the meetings are held. Though $95 \%$ of respondents think that WUAs are important, only $58 \%$ of all the respondents have the willingness to participate in WUAs. Considering the function and role of WUAs, most respondents (87.5\%) think WUAs help reduce and resolve water disputes in irrigation affairs and manage water issues better. Other roles of WUAs that are recognized by farmers, including its effectiveness in promoting more transparent water allocation, more reasonable water charges and irrigation arrangement. In terms of water use improvement, only $25 \%$ of the farmers think that WUAs play an important role in saving water. In addition, most of the farmers did not think WUAs help ensure water supply during irrigation. 
Table 3. Quantification of small-scale farmers' perceptions of WUAs.

\begin{tabular}{cc}
\hline Survey Items ${ }^{1}$ & Percentage \\
\hline Farmers that understand the purposes of WUAs & 62 \\
Farmers know that the meetings held regularly & 75 \\
Farmers think that WUAs are important & 95 \\
Farmers' willingness to participate in WUAs & 58 \\
Help manage water issues better & 36 \\
Promote water saving & 25 \\
Reduce or resolve water disputes & 69 \\
Ensure more transparent water allocation & 27 \\
Reasonable arrangement of irrigation & 27 \\
More reasonable water charges & 24 \\
Ensure water supply for irrigation & 8 \\
\hline
\end{tabular}

Farmers' participation level in WUAs is depicted in Table 4 . Only $40 \%$ of the respondents said they had participated in the WUA meetings at least once in a year, and the average meetings held in a year are 3.5 times. Women participation is relatively low; the proportion of women is $23 \%$ among the all participators. About $30 \%$ of the respondents said they have participated in the WUA election meetings. In terms of transparency and accountability of the WUA decision-making processes, a large proportion of respondents $(47 \%)$ said only very important things are decided by most farmers involved during the meetings. However, $33 \%$ of farmers think that only elite farmers in the village participate in the decision of some things, and $20 \%$ of farmers thought that farmers are not involved in the decision process and that things are merely decided by WUA leaders.

Table 4. Farmers' participation level in WUAs and decision-making process of WUAs.

\begin{tabular}{cc}
\hline Survey Items & Percentage \\
\hline Farmers participated in irrigation management & 40 \\
Average meetings held in a year (Times) & 3.5 \\
The proportion of women in participation & 23 \\
Farmers that have participated in the WUA elections & 30 \\
Only very important things are decided by most farmers involved & 47 \\
Only individual farmers participate in the decision of some things & 33 \\
Farmers are not involved in irrigation management & 20 \\
\hline
\end{tabular}

From the above analysis, we can see that WUAs are still not operating in accordance with their designed objectives, which is not well recognized among farmers. Farmers' understanding of WUAs is not clear and distinct, and the motivation of participation is not strong. However, a large portion $(95 \%)$ of the respondents acknowledged the roles of WUAs in managing irrigation water resources and providing necessary services (such as formulating water use plans, imposing water fees and resolving water disputes and conflicts). A full participation of farmers and a more transparent decision making process is needed to ensure the role of WUAs in water management. Furthermore, there are also many challenges facing WUAs such as inadequate funding, lack of revenues and technical capacity.

\subsection{Impacts of Farmers' Participation in WUAs on IWUE}

The coefficients for the determinants of TE and IWUE were reported in Table 5. Notably, in the process of regression on TE-influencing factors, the dependent variable is the technical inefficiency value $u_{i t}$. Therefore, the negative sign of coefficients indicates a positive relationship between TE and variables under consideration. As for IWUE, the positive sign indicates a positive relationship between IWUE and influencing factors. 
Table 5. Determinants of technical inefficiency and irrigation water use efficiency.

\begin{tabular}{|c|c|c|}
\hline \multirow{2}{*}{ Independent Variables } & TE & IWUE \\
\hline & Coefficients & Coefficients \\
\hline Age & $\begin{array}{c}0.011 \\
(0.004)^{* * *}\end{array}$ & $\begin{array}{c}0.009 \\
(0.14)^{* *}\end{array}$ \\
\hline Education & $\begin{array}{l}-0.021 \\
(0.01)^{*}\end{array}$ & $\begin{array}{c}0.047 \\
(0.01)^{* * *}\end{array}$ \\
\hline Income & $\begin{array}{l}-0.006 \\
(0.342)\end{array}$ & $\begin{array}{c}-0.019 \\
(1.82)\end{array}$ \\
\hline Off-farm income & $\begin{array}{c}0.101 \\
(-0.140)\end{array}$ & $\begin{array}{l}-0.136 \\
(0.13)^{*}\end{array}$ \\
\hline Farming years & $\begin{array}{c}-0.0165 \\
(0.004)^{* * *}\end{array}$ & $\begin{array}{c}0.015 \\
(0.005)^{* * *}\end{array}$ \\
\hline Family size & $\begin{array}{c}0.017 \\
(0.007) * *\end{array}$ & $\begin{array}{c}0.023 \\
(0.004)^{* *}\end{array}$ \\
\hline Total land holding & $\begin{array}{c}-0.007 \\
(0.003)^{* * *}\end{array}$ & $\begin{array}{c}0.003 \\
(-0.003)\end{array}$ \\
\hline Number of plots & $\begin{array}{l}-0.195 \\
(0.05)^{*}\end{array}$ & $\begin{array}{l}-0.089 \\
(0.07)^{*}\end{array}$ \\
\hline Only maize planted $(\mathrm{Yes}=1 ; \mathrm{No}=0)$ & $\begin{array}{c}0.036 \\
(0.002)^{* *}\end{array}$ & $\begin{array}{c}0.942 \\
(-0.12)\end{array}$ \\
\hline Cement canal lining $(\mathrm{Yes}=1 ; \mathrm{No}=0)$ & & $\begin{array}{c}1.043 \\
(-0.009)\end{array}$ \\
\hline Plastic mulch $(\mathrm{Yes}=1 ; \mathrm{No}=0)$ & & $\begin{array}{c}0.024 \\
(0.05)^{* *}\end{array}$ \\
\hline Irrigation from Pumping well $(\mathrm{Yes}=1 ; \mathrm{No}=0)$ & & $\begin{array}{c}0.076 \\
(0.006) * * *\end{array}$ \\
\hline water price & & $\begin{array}{c}0.064 \\
(0.005)^{* * *}\end{array}$ \\
\hline Have Participated in irrigation meetings held by WUA $($ Yes $=1 ; \mathrm{No}=0)$ & & $\begin{array}{c}1.207 \\
(0.002)^{* * *}\end{array}$ \\
\hline WUA leaders $($ Yes $=1 ;$ No $=0)$ & & $\begin{array}{c}0.971 \\
(-0.08)\end{array}$ \\
\hline Have expressed their opinions $($ Yes $=1 ; \mathrm{No}=0)$ & & $\begin{array}{c}0.776 \\
(0.004)^{* *}\end{array}$ \\
\hline Constant & $\begin{array}{c}0.468 \\
(0.051)\end{array}$ & $\begin{array}{c}0.198 \\
(0.231)\end{array}$ \\
\hline
\end{tabular}

Notes: Absolute value of t-statistics in parentheses. ${ }^{*}$ Significant at $10 \% ;{ }^{* *}$ Significant at $5 \%$; ${ }^{* * *}$ Significant at $1 \%$.

Our results show that attending in the WUA meetings has a positively significant impact on farmers' IWUE improvement. That is sensible because participation in WUA meetings helps farmers to get to know newly implemented agriculture policies, and irrigation and agriculture technologies. It helps strengthen farmers' perceptions of water scarcity and significance of water savings. However, the magnitude of the effect is small, indicating the role of PIM in IWUE improvement is limited in the current situation. This is partly because there is a lack of transparent management mechanisms in current WUAs organizations. Farmers' understanding of WUAs is not comprehensive, and their participation mostly becomes a mere formality. This also leads to negative influences of the WUA achievements. During our survey, we find that farmers' willingness to take part in WUA management is not strong. Only a small proportion of farmers have essentially been involved in irrigation decision-making during the WUA meetings. To be a WUA leader will not significantly improve IWUE at household level. That may be because most WUA leaders are also village cadres in the study area, and they are usually not full-time farmers, so the time spent on irrigation is not as much compared to full-time farmers. Whether farmers have fully reflected their views on the agricultural production 
affairs during the meeting will provide insight in the democracy status of the WUAs. The dummy variable that whether farmers have expressed their opinions during the meeting is a proxy of farmers' participation level. Results indicate that farmers' communication in WUA will significantly influence IWUE in the positive way. To promote participatory irrigation management and the full involvement of small-scale farmers, our study indicates that the creation of WUAs results in IWUE improvement.

Other factors also have significant impacts on maize production IWUE. Among the characteristics of household laborers and decision makers, age, family size and farming years are positively and significantly affecting households' IWUE. It indicates that older farmers are more technically efficient than younger farmers. This can be explained that older farmers have more farming experience, and thus have developed more efficient irrigation practices. Family size is an important indicator of household laborers. More laborers available on farm means more laborers on irrigation water management. Years of farming is also an important indicator of farmers' experience in agricultural production. This is in accord with age variable because the years of farming are longer for the elderly ones. However, off-farm income has significant negative impacts on IWUE. This finding is different from previous studies, which show that off-farm income helps farmers obtain higher irrigation efficiency by providing financial support to irrigation investment and technologies. However, the negative sign of off-farm income may be explained that farmers who have more off-farm income will devote less time on agricultural production and thus irrigation. Off-farm income accounts for more than $55 \%$ of farmers' total income on average in our sample. Other variables are not significant in our case study; for example education and income have no significant impacts on the IWUE. Total land holding and the number of plots are negative significantly influencing the IWUE. It indicates that small-scale farms are less efficient in irrigation water use.

The influences of irrigation infrastructure and technology on IWUE are measured through cement canal lining and plastic mulch. We can see that the adoption of cement canal lining and layout of plastic mulch help to improve IWUE significantly. Cement canal lining and plastic mulch are the most widely adopted water-saving measures in the study area. However, there are criticisms of them for the ecological damage they may cause. Ecologists blamed cement lining for preventing water infiltration into the soil and thus leading to the death of plants near the channel, which results in a deteriorating riverside ecological environment. Plastic mulch pollution is serious in northwestern China, and how to resolve the plastic mulch pollution is a pending issue at present. The robust positive relationship between groundwater use and IWUE indicates that groundwater use in irrigation helps to improve IWUE. This is in line with previous studies, that IWUE is relatively high in areas irrigated by groundwater and lower in surface water areas $[10,46]$.

Irrigation water price has been considered an important management instrument to improve IWUE $[47,48]$. Researchers have found that previous water price needs to be raised to a relatively high level to be elastic $[49,50]$. The robust positive sign in Table 5 indicates that pricing water higher helps to improve IWUE in the study area. The effectiveness of demand management policy tools, such as water pricing, to promote the efficient use of water resources has been verified in several studies $[10,42,50]$. The findings in our study concerning water price provides empirical evidence on irrigation water management. However, the price instrument should be implemented with caution. During the survey, we perceived that farmers' attitudes towards water price are not optimistic and that water pricing reform has caused strong disapproval among farmers.

\section{Conclusions}

This study examines farmers' IWUE in maize production in northwestern China. The empirical results show that farmers' IWUE of maize production is much lower than TE in the study area, with values are 0.24 and 0.74 respectively. Considering the big variance of IWUE among farmers, there is still room for the IWUE to be improved extensively in the study area. Also, the large gap between IWUE and TE indicates that IWUE can be improved given existing technology. Improvement in IWUE will lead to substantial decreases in agricultural water use without compromising the 
agricultural production. In addition, the saved water then can be reallocated to other uses to improve socio-economic water productivity.

Farmers' water user associations (WUAs) have become increasingly common in northwestern China and were used as the organizational foundation for water allocation. Famers' participation in irrigation management through WUAs has positive influence on IWUE improvement, but the effect is not obvious. Participation in WUA meetings is an important way for farmers to become involved in irrigation management. That is partly because most farmers' perceptions of WUAs are not comprehensive, and the willingness to take part in WUA management is not strong. Only a small proportion of farmers have been essentially involved in irrigation decision-making during the WUA meetings. There is an urgent need to reform the traditional management form of WUA to make it more transparent, fair, and extensively participated among farmers.

Water price, as a market-based instrument, has been widely adopted in water resource management in agriculture. The irrigation water price was verified to be positively significant in improving IWUE in our study. That means the proper use of price instruments will provide sufficient incentives for farmers to improve irrigation management, which helps to achieve efficient allocation of water resources in different users. Though raising the price of water can help to improve IWUE, the subsequent influence on agricultural production caused by water price increases should be considered. Thoughtful and comprehensive investigation and evaluation should be conducted before a water price reform.

Several other factors are also found to affect IWUE in our research data. Farmers' experience, which accumulates with age and farming years, has positively significant influenced the IWUE. Adoption of water saving irrigation technology, such as cement canal lining and use of plastic film, helps to improve farmers' IWUE. Our results also show that groundwater used in irrigation will have positive impacts on IWUE. Farmers' off-farm income was found to be negatively significant to IWUE indicating that farmers with more off-farm income will devote less time on agricultural production and thus irrigation management. The negative signs of total land holding and number of plots showed that smaller farms are more likely to obtain higher IWUE. Farmers' education level, income and planting structure have no significant impacts on IWUE.

Our findings have important implications for the agriculture water management in arid and semi-arid areas in northwestern China. Increasing IWUE is of crucial importance for maintaining food self-sufficiency and improving water productivity in water-scarce regions. Consequently, it may also contribute to improving the ecological environment in the downstream reaches of northwestern China's inland rivers. The limitation of this study is a lack of deep investigation of the key factors that influence farmers' participation in irrigation management, which deserves further study.

Acknowledgments: This research was financially supported by a grant from the major research plan of the National Natural Science Foundation of China (Grant No. 91325302). Data support from the research projects of the National Natural Science Foundation of China (Grant No. 91425303; Grant No. 71225005) is also acknowledged.

Author Contributions: Xiangzheng Deng designed the research topic; Zhihui Li shared efforts in data analysis; Feng Wu contributed to the methodology of the study; Qing Zhou drafted and edited the manuscript; Wei Song provided suggestions to revise the paper.

Conflicts of Interest: The authors declare no conflict of interest.

\section{References}

1. Mariolakos, I. Water resources management in the framework of sustainable development. Desalination 2007, 213, 147-151. [CrossRef]

2. Deng, X.; Huang, J.; Rozelle, S.; Zhang, J.; Li, Z. Impact of urbanization on cultivated land changes in China. Land Use Policy 2015, 45, 1-7. [CrossRef]

3. Fischer, G.; Tubiello, F.N.; Van Velthuizen, H.; Wiberg, D.A. Climate change impacts on irrigation water requirements: Effects of mitigation, 1990-2080. Technol. Forecast. Soc. Chang. 2007, 74, 1083-1107. [CrossRef] 
4. Deng, X.; Singh, R.B.; Liu, J.; Güneralp, B. Physical and economic processes of water scarcity and water allocation for integrated river basin management. Phys. Chem. Earth 2015, 79. [CrossRef]

5. Knox, J.; Hess, T.; Daccache, A.; Wheeler, T. Climate change impacts on crop productivity in Africa and south Asia. Environ. Res. Lett. 2012, 7, 034032. [CrossRef]

6. Cheng, G.; Li, X.; Zhao, W.; Xu, Z.; Feng, Q.; Xiao, S.; Xiao, H. Integrated study of the water-ecosystem-economy in the Heihe River Basin. National Sci. Rev. 2014, 1, 413-428. [CrossRef]

7. Tilman, D.; Cassman, K.G.; Matson, P.A.; Naylor, R.; Polasky, S. Agricultural sustainability and intensive production practices. Nature 2002, 418, 671-677. [CrossRef] [PubMed]

8. Rosegrant, M.W.; Cline, S.A. Global food security: Challenges and policies. Science 2003, 302, $1917-1919$. [CrossRef] [PubMed]

9. Deng, X.; Zhao, C. Identification of water scarcity and providing solutions for adapting to climate changes in the Heihe River Basin of China. Adv. Meteorol. 2015, 2015, 279173. [CrossRef]

10. Yin, N.; Huang, Q.; Yang, Z.; Wang, Y. Impacts of off-farm employment on irrigation water efficiency in north china. Water 2016, 8, 452. [CrossRef]

11. Singh, R.; Kundu, D.; Bandyopadhyay, K. Enhancing agricultural productivity through enhanced water use efficiency. J. Agric. Phys. 2010, 10, 1-15.

12. Ahmad, M.T.; Haie, N.; Yen, H.; Tuqan, N. Sefficiency of a water use system: The case of Kano River Irrigation Project, Nigeria. Int. J. Civ. Eng. 2017. [CrossRef]

13. Kaneko, S.; Tanaka, K.; Toyota, T.; Managi, S. Water efficiency of agricultural production in china: Regional comparison from 1999 to 2002. Int. J. Agric. Res. Gov. Ecol. 2004, 3, 231-251. [CrossRef]

14. Reinhard, S.; Lovell, C.A.K.; Thijssen, G. Econometric estimation of technical and environmental efficiency: An application to Dutch dairy farms. Am. J. Agric. Econ. 1999, 81, 44-60. [CrossRef]

15. Dhehibi, B.; Lachaal, L.; Elloumi, M.; Messaoud, A. Measuring irrigation water use efficiency using stochastic production frontier: An application on citrus producing farms in Tunisia. Afr. J. Agric. Res. Econ. 2007, 1, $1-15$.

16. Speelman, S.; D’Haese, M.; Buysse, J.; D’Haese, L. A measure for the efficiency of water use and its determinants, a case study of small-scale irrigation schemes in north-west province, South Africa. Agric. Syst. 2008, 98, 31-39. [CrossRef]

17. Gadanakis, Y.; Bennett, R.; Park, J.; Areal, F.J. Improving productivity and water use efficiency: A case study of farms in England. Agric. Water Manag. 2015, 160, 22-32. [CrossRef]

18. Wang, X.Y. Irrigation water use efficiency of farmers and its determinants: Evidence from a survey in northwestern china. Agric. Sci. China 2010, 9, 1326-1337. [CrossRef]

19. Smout, I.K.; Gorantiwar, S.D. Productivity and equity of different irrigation schedules under limited water supply. J. Irrig. Drain. Eng. 2006, 132, 349-358. [CrossRef]

20. Gleick, P.H. Global freshwater resources: Soft-path solutions for the 21st century. Science 2003, 302, 1524-1528. [CrossRef] [PubMed]

21. Cai, X.M.; Rosegrant, M.W. Optional water development strategies for the yellow river basin: Balancing agricultural and ecological water demands. Water Resour. Res. 2004, 40. [CrossRef]

22. Huitema, D.; Mostert, E.; Egas, W.; Moellenkamp, S.; Pahl-Wostl, C.; Yalcin, R. Adaptive water governance: Assessing the institutional prescriptions of adaptive (co-)management from a governance perspective and defining a research agenda. Ecol. Soc. 2009, 14, 26. [CrossRef]

23. Hu, X.J.; Xiong, Y.C.; Li, Y.J.; Wang, J.X.; Li, F.M.; Wang, H.Y.; Li, L.L. Integrated water resources management and water users' associations in the arid region of northwest china: A case study of farmers' perceptions. J. Environ. Manag. 2014, 145, 162-169. [CrossRef] [PubMed]

24. Wang, J.; Huang, J.; Zhang, L.; Huang, Q.; Rozelle, S. Water Governance and Water Use Efficiency: The Five Principles of Wua Management and Performance in China. J. Am. Water Resour. Assoc. 2010, 46, 665-685. [CrossRef]

25. Qiao, G.H.; Zhao, L.J.; Klein, K.K. Water user associations in Inner Mongolia: Factors that influence farmers to join. Agric. Water Manag. 2009, 96, 822-830. [CrossRef]

26. Huang, Q.Q.; Wang, J.X.; Easter, K.W.; Rozelle, S. Empirical assessment of water management institutions in northern china. Agric. Water Manag. 2010, 98, 361-369. [CrossRef]

27. Calow, R.C.; Howarth, S.E.; Wang, J.X. Irrigation development and water rights reform in China. Int. J. Water Resour. Dev. 2009, 25, 227-248. [CrossRef] 
28. Meinzen-Dick, R. Beyond panaceas in water institutions. Proc. Natl. Acad. Sci. USA 2007, 104, $15200-15205$. [CrossRef] [PubMed]

29. Corcoles, J.I.; de Juan, J.A.; Ortega, J.F.; Tarjuelo, J.M.; Moreno, M.A. Management evaluation of water users associations using benchmarking techniques. Agric. Water Manag. 2010, 98, 1-11. [CrossRef]

30. Zhang, L.; Heerink, N.; Dries, L.; Shi, X. Water users associations and irrigation water productivity in northern china. Ecol. Econ. 2013, 95, 128-136. [CrossRef]

31. Bhatt, S. How does participatory irrigation management work? A study of selected water users' associations in Anland district of Gujarat, western India. Water Policy 2013, 15, 223-242. [CrossRef]

32. Yu, H.Y. Can water users' associations improve water governance in China? A tale of two villages in the Shiyang river basin. Water Int. 2016, 41, 966-981. [CrossRef]

33. Cai, X.M. Water stress, water transfer and social equity in northern China-implications for policy reforms. J. Environ. Manag. 2008, 87, 14-25. [CrossRef] [PubMed]

34. Blaikie, P. Is small really beautiful? Community-based natural resource management in Malawi and Botswana. World Dev. 2006, 34, 1942-1957. [CrossRef]

35. Senanayake, N.; Mukherji, A.; Giordano, M. Re-visiting what we know about irrigation management transfer: A review of the evidence. Agric. Water Manag. 2015, 149, 175-186. [CrossRef]

36. Wang, J.X.; Huang, J.K.; Xu, Z.G.; Rozelle, S.; Hussain, I.; Biltonen, E. Irrigation management reforms in the yellow river basin: Implications for water saving and poverty. Irrig. Drain. 2007, 56, 247-259. [CrossRef]

37. Huang, Q.Q. Impact evaluation of the irrigation management reform in northern china. Water Resour. Res. 2014, 50, 4323-4340. [CrossRef]

38. Battese, G.E.; Coelli, T.J. A model for technical inefficiency effects in a stochastic frontier production function for panel data. Empir. Econ. 1995, 20, 325-332. [CrossRef]

39. Chebil, A.; Frija, A.; Abdelkafi, B. Irrigation water use efficiency in collective irrigated schemes of Tunisia: Determinants and potential irrigation cost reduction. Agric. Econ. Rev. 2012, 13, 39.

40. Yigezu, Y.A.; Ahmed, M.A.; Shideed, K.; Aw-Hassan, A.; El-Shater, T.; Al-Atwan, S. Implications of a shift in irrigation technology on resource use efficiency: A syrian case. Agric. Syst. 2013, 118, 14-22. [CrossRef]

41. Tang, J.J.; Folmer, H.; Xue, J.H. Technical and allocative efficiency of irrigation water use in the Guanzhong plain, China. Food Policy 2015, 50, 43-52. [CrossRef]

42. Speelman, S.; Buysse, J.; Farolfi, S.; Frija, A.; D'Haese, M.; D’Haese, L. Estimating the impacts of water pricing on smallholder irrigators in north west province, South Africa. Agric. Water Manag. 2009, 96, 1560-1566. [CrossRef]

43. Shah, T.; Hassan, M.U.; Khattak, M.Z.; Banerjee, P.S.; Singh, O.; Rehman, S.U. Is irrigation water free? A reality check in the Indo-Gangetic Basin. World Dev. 2009, 37, 422-434. [CrossRef]

44. Bravo-Ureta, B.E.; Solís, D.; López, V.H.M.; Maripani, J.F.; Thiam, A.; Rivas, T. Technical efficiency in farming: A meta-regression analysis. J. Prod. Anal. 2007, 27, 57-72. [CrossRef]

45. Tanner, C.; Sinclair, T. Efficient water use in crop production: Research or re-search? In Limitations to Efficient Water Use in Crop Production; American Society of Agronomy: Madison, WI, USA, 1983; pp. 1-27.

46. Fishman, R.; Devineni, N.; Raman, S. Can improved agricultural water use efficiency save India's groundwater? Environ. Res. Lett. 2015, 10, 084022. [CrossRef]

47. Cummings, R.G.; Nercissiantz, V. The use of water pricing as a means for enhancing water use efficiency in irrigation: Case studies in Mexico and the United States. Nat. Res. J. 1992, 32, 731.

48. Huang, Q.Q.; Rozelle, S.; Howitt, R.; Wang, J.X.; Huang, J.K. Irrigation water demand and implications for water pricing policy in rural china. Environ. Dev. Econ. 2010, 15, 293-319. [CrossRef]

49. Zhou, Q.; Wu, F.; Zhang, Q. Is irrigation water price an effective leverage for water management? An empirical study in the middle reaches of the Heihe River Basin. Phys. Chem. Earth Parts A/B/C 2015, 89, 25-32. [CrossRef]

50. Sun, T.H.; Wang, J.X.; Huang, Q.Q.; Li, Y.R. Assessment of water rights and irrigation pricing reforms in Heihe River Basin in China. Water 2016, 8, 333. [CrossRef]

(C) 2017 by the authors. Licensee MDPI, Basel, Switzerland. This article is an open access article distributed under the terms and conditions of the Creative Commons Attribution (CC BY) license (http:/ / creativecommons.org/licenses/by/4.0/). 